\title{
KELAYAKAN BUKU SANTUN BERBAHASA UNTUK PENGASUHAN BERBAHASA PESERTA DIDIK TK DI KABUPATEN KUDUS
}

\author{
Ristiyani $^{1 凶}$, Mila Roysa $^{2}$, Fina Fakhriyah $^{3}$ \\ ${ }^{1}$ Prodi Pendidikan Bahasa Indonesia, ${ }^{2}$ Prodi Pendidikan Guru Sekolah Dasar, Fakultas Keguruan dan \\ Ilmu Pendidikan \\ Universitas Muria Kudus, Indonesia
}

\section{Info Artikel}

Sejarah Artikel:

Diterima Maret 2017

Disetujui Mei 2017

Dipublikasikan Juni 2017

Keywords:

politeness of speech,

parenting, and preschool

children

\begin{abstract}
The purpose of this study was to measure the feasibility of well mannered language book for parenting the preschool-aged children in Kudus regency. Based on feasibility test that had been executed, it was obtained feasibility test score from linguist with feasibility aspect of writing, feasibility of content, feasibility of language use, feasibility of presentation, and feasibility of graph, it was obtained result equal to $78,3 \%$ which meant in feasible category. $83.5 \%$ score was obtained from the feasibility test of the material expert with the aspect of the feasibility of the grammar, the feasibility of the content, the feasibility of language use, the feasibility of presentation, and the feasibility of graph which meant in the very feasible category. Feasibility test from module expert with aspect of grammar, content feasibility, feasibility of language use, feasibility of presentation, and feasibility of graph, it was obtained the score of $90 \%$ in very feasible category. Based on these data, it could be concluded that the well mannered language book that had received input of the linguists experts, materials (psychologists), and teachers was very feasible in the category.
\end{abstract}

(C) 2017 Universitas Muria Kudus

\begin{tabular}{lc}
\hline Alamat korespondensi: & p-ISSN 2087-9385 \\
Program Studi Pendidikan Guru Sekolah Dasar & e-ISSN 2528-696X \\
Fakultas Keguruan dan Ilmu Pendidikan Universitas Muria Kudus & \\
Kampus UMK Gondangmanis, Bae Kudus Gd. L. It I PO. BOX 53 & \\
Kudus & \\
Tlp (0291) 438229 ex.147 Fax. (0291) 437198 & \\
E-mail: ristivani@umk.ac.id &
\end{tabular}




\section{PENDAHULUAN}

Kemauan dan kemampuan guru dalam memilih tuturan yang santun, baik berdasarkan jenis, bentuk, dan modusnya merupakan salah satu indikator kecakapan berkomunikasi yang perlu dicontohkan kepada peserta didik. Akan tetapi, bentuk-bentuk tuturan di lingkungan Taman Kanak-Kanak (TK) kabupaten Kudus mengandung maksud sangat beragam, bergantung pada konteks situasional, sosial, dan kultural yang mengiringi tuturan tersebut. Kenyataan menunjukkan bahwa tindak berbahasa dalam interakasi pengasuhan di TK, baik dalam aktivitas formal maupun nonformal dalam kaitannya dengan strategi bertutur, teknik bertutur, implikatur percakapan dan daya pragmatik, prinsip sopan santun menjadi langsung literal dan instan, sehingga cenderung tidak santun.

Berpijak hasil observasi prapenelitian di TK Negeri Pembina Kudus terdapat masalah pada percakapan anak-anak. Mereka cenderung banyak menggunakan tindak tutur ilokusi direktif dalam percakapan konteks formal di dalam kelas maupun nonformal di luar kelas. Anak-anak pada waktu meminta sesuatu menggunakan tuturan yang terkadang terdengar kurang santun, terkesan memaksa mitra tuturnya untuk melakukan permintaan penutur. Hal ini ditunjukkan oleh tekanan suara keras si anak didik, baik untuk menyatakan informasi maupun untuk memerintah yang dapat membuat mitra tutur kurang memahami maksud penutur, sehingga mitra tutur merasa kebingungan untuk menyatakan maksud penutur. Perhatikan kutipan beirkut ini.

(1.a) "Bu, yang ini ditebali?"

(1.b) "Bu, kapan Bu?"

(1.c) "Cepet Bu."

Ketiga kutipan di atas apabila didengarkan sepintas kurang dipahami dan membingungkan mitra tutur. Kalimat (1.a) " $\mathrm{Bu}$, yang ini ditebali?" dan kalimat (1.b) "Bu, kapan Bu?" merupakan kalimat penutur yang meminta sekaligus memaksa mitra tutur untuk melakukan sesuatu. Akan tetapi, diucapkan dengan kalimat yang singkat sehingga membingungkan mitra tutur. Adapun untuk kalimat (1.c) "Cepet Bu." merupakan kalimat permintaan yang secara tidak langsung memaksa mitra tutur untuk memberikan waktu istirahat kepada penutur. Faktor lain datang dari individu penutur yang memang mempunyai sikap suka meminta, menyuruh, bahkan memaksa. Selain itu, terlihat juga dari latar belakang penutur bahasa yang mempunyai tingkat sosial yang merasa lebih tinggi dari penutur bahasa lain.

Peserta didik Sebagai bagian dari suatu kelompok masyarakat, juga belajar bagaimana bersikap ketika mereka terlibat dalam percakapan. Ada sejumlah aturan yang harus mereka pelajari ketika mereka berinteraksi dengan orang lain; salah satu aturan itu yakni kesantunan. Di dalam kesantunan, peserta didik belajar sejumlah aturan yang mengatur tuturan ketika mereka terlibat dalam percakapan dengan orang lain. Kesantunan merupakan sebuah istilah yang berkaitan dengan kesopanan, rasa hormat, sikap yang baik atau perilaku yang pantas.

Keterkaitan kesantunan dengan "tindakan yang sesuai" dalam kehidupan seharihari, menegaskan bahwa kesantunan tidak hanya berkaitan dengan bahasa, melainkan juga dengan perilaku nonverbal. Keterkaitan itu menjadi menarik karena kesantunan menjadi titik pertemuan antara bahasa dan realitas sosial (Eelen 2001:4). Sebagaimana halnya dengan aturan perilaku dan etika, kesantunan menghubungkan bahasa dengan berbagai aspek sosial.

Dalam pemerolehan bahasa, kesantunan merupakan unsur yang sangat penting. Apa yang didengar oleh peserta didik di sekolah dan di rumah, maka akan ditiru. Apabila yang diperoleh peserta didik adalah tuturan yang tidak santun, maka yang diucapkannya pun menjadi tidak santun. Kesantunan dapat memperlancar interaksi antarindividu, baik di sekolah maupun di rumah. Kesantunan dipelajari oleh anak-anak sejak kecil melalui lingkungan sosial mereka. Peran keluarga, terutama pengasuh dan orang tua, sangat penting dalam proses ini. Ketika mereka memasuki sekolah, anak-anak menguatkan pengetahuan mereka mengenai kesantunan melalui guru dan teman sebaya. Anak-anak belajar bagaimana mengungkapkan kesetujuan, mengungkapkan penolakan, menyapa orang, menyampaikan keinginan, mengungkapkan keingintahuan, dan lainnya.

Interaksi pengasuhan anak-anak di TK merupakan interaksi yang kompleks dan sangat menarik. Interaksi pengasuhan menjadi hal yang menarik dan penting untuk dianalisis karena seiring dengan interaksi fisik, interaksi verbal, interaksi budaya, dan interaksi kepribadian. Norma-norma kesantunan tampak dalam interaksi dalam perilaku verbal maupun perilaku nonverbal pemakainya. Tindakan verbal dalam fungsi direktif misalnya, ditunjukkan pada bagaimana guru mengungkapkan nasihat, perintah, permohonan, keharusan, permintaan, dan larangan melakukan sesuatu kepada peserta didik. Adapun tindakan nonverbal tampak dari gerakgerik fisik yang menyertainya. Kondisi ideal yang diharapkan masih belum bisa terwujud dalam latar percakapan pengasuhan di kelas. Masih banyak ditemukan ketidaksesuaian tindakan verbal berupa kata-kata umpatan, cemoohan, dan pelecehan. 
Berdasarkan pengamatan pada dua buku pengasuhan berbahasa yang beredar di pasaran, terdapat karakteristik berikut.
(2012) modul yang baik adalah modul yang memenuhi tiga komponen kelayakan menurut Badan Standar Nasional Pendidikan (BSNP),

Tabel 1. Karakteristik pengasuhan berbahasa yang beredar di pasaran

\begin{tabular}{|c|c|c|}
\hline \multirow[t]{2}{*}{ Komponen } & \multicolumn{2}{|l|}{ Karakteristik Buku } \\
\hline & Buku (1) & Buku (2) \\
\hline Judul tiap kegiatan & $\begin{array}{l}\text { Judul digantikan dengan tema } \\
\text { pembelajaran. }\end{array}$ & $\begin{array}{l}\text { Menuliskan judul setiap kegiatan dan } \\
\text { tema kegiatan. }\end{array}$ \\
\hline $\begin{array}{l}\text { Komponen setiap } \\
\text { pembelajaran }\end{array}$ & $\begin{array}{l}\text { Memuat: tema, lingkup perkembangan, } \\
\text { indikator, uraian petunjuk kegiatan, } \\
\text { gambar/ilustrasi, latihan/tugas, dan kolom } \\
\text { nilai. }\end{array}$ & $\begin{array}{l}\text { Memuat: judul kegiatan, tema, tujuan } \\
\text { pembelajaran, indikator, uraian petunjuk } \\
\text { kegiatan, gambar/ilustrasi, latihan/tugas, } \\
\text { dan kolom nilai. }\end{array}$ \\
\hline $\begin{array}{l}\text { Rumusan tujuan } \\
\text { pembelajaran }\end{array}$ & Tidak ada & $\begin{array}{l}\text { Tujuan pembelajaran dirumuskan secara } \\
\text { gramatik, santun, dan komunikatif. }\end{array}$ \\
\hline $\begin{array}{l}\text { Model kalimat } \\
\text { petunjuk latihan }\end{array}$ & $\begin{array}{l}\text { Dominan menggunakan modus imperatif } \\
\text { langsung dengan variasi partikel -lah } \\
\text { maupun tidak. }\end{array}$ & $\begin{array}{l}\text { Dominan menggunakan modus imperatif } \\
\text { langsung dengan variasi partikel -lah } \\
\text { maupun tidak. }\end{array}$ \\
\hline Kata sapaan & Tidak ditemukan & Sapaan kalian \\
\hline $\begin{array}{l}\text { Teks bacaan dan } \\
\text { teks sastra }\end{array}$ & $\begin{array}{l}\text { Teks mengandung muatan karakter tanpa } \\
\text { memasukkan muatan kesantunan. }\end{array}$ & $\begin{array}{l}\text { Teks mengandung muatan karakter tanpa } \\
\text { memasukkan muatan kesantunan. }\end{array}$ \\
\hline $\begin{array}{l}\text { Materi aspek } \\
\text { mendengarkan dan } \\
\text { berbicara }\end{array}$ & $\begin{array}{l}\text { Tanpa dilengkapi dengan CD/ } \\
\text { kaset/multimedia, yang ditulis dalam buku } \\
\text { hanyalah gambar/ilustrasinya saja. }\end{array}$ & $\begin{array}{l}\text { Tanpa dilengkapi dengan } \\
\mathrm{CD} / \mathrm{kaset} / \mathrm{multimedia,} \text { yang ditulis dalam } \\
\text { buku hanyalah gambar/ilustrasinya saja. }\end{array}$ \\
\hline Kegrafikaan & $\begin{array}{l}\text { Gambar sampul berwarna, variasi huruf } \\
\text { sesuai komponen yang ditonjolkan, huruf } \\
\text { tidak hitam saja, dan ukuran huruf } \\
\text { standar. }\end{array}$ & $\begin{array}{l}\text { Gambar sampul berwarna pada halaman } \\
\text { judul, variasi huruf sesuai komponen yang } \\
\text { ditonjolkan, huruf warna hitam saja, dan } \\
\text { ukuran huruf standar. }\end{array}$ \\
\hline $\begin{array}{l}\text { Kertas dan } \\
\text { Penjilidan }\end{array}$ & Jenis kertas A5 80 gram dan dijilid kuat. & Jenis kertas A5 80 gram dan dijilid kuat. \\
\hline $\begin{array}{l}\text { Bagian Penyudah } \\
\text { Buku }\end{array}$ & Tidak ada & Tidak ada \\
\hline
\end{tabular}

Adapun buku yang beredar di pasaran yang dimaksud yakni buku (1) Aku Pintar Berbahasa: Pelajaran Bahasa Indonesia untuk TK B, dan buku (2) Ayo Jadi Anak Pintar Berbahasa Indonesia. Keduanya merupakan buku pegangan yang digunakan guru di TK Negeri Pembina Kudus. Kedua buku tersebut belum memasukkan muatan kesantunan, belum menggunakan kata sapaan, dan menggunakan modus imperatif dengan variasi partikel -lah. Berdasar dari data hasil pengamatan di atas, maka peneliti menyusun buku santun berbahasa untuk pengasuhan berbahasa pada peserta didik TK di kabupaten Kudus.

Buku santun berbahasa disusun dalam upaya memberikan pengetahuan kepada guru tentang pentingnya kesantunan. Hal tersebut sejalan dengan program pemerintah tentang revitalisasi pola pikir masyarakat. Semakin sering anak mendengar bahasa yang santun, maka semakin besar kemungkinan mereka untuk meniru menjadi santun dalam berbahasa.

Buku santun berbahasa ini dikembangkan dengan teknik pengemasan kembali informasi yang sudah ada agar memenuhi standar yang ditentukan. Buku atau modul yang dikembangkan harus memenuhi standart penilaian kelayakan oleh pakar. Menurut Millah et al. yakni komponen kelayakan isi, kelayakan bahasa, dan kelayakan penyajian. Tujuan dalam penelitian ini untuk mendeskripsikan kelayakan buku santun berbahasa dalam pengasuhan berbahasa peserta didik TK di kabupaten Kudus.

\section{METODE PENELITIAN}

Jenis penelitian yang digunakan penelitian Research and Development (R\&D) model Gall, Meredith D., Joyce P. Gall, dan Walter R. Borg (1983). Tahapan penelitian pengembangan menurut Gall, Meredith D., Joyce P. Gall, dan Walter R. Borg (1983) terdiri atas 4 tahap. Pertama, studi pendahuluan, kajian teori, dan analisis kebutuhan. Tujuan tahap ini yakni untuk mendapatkan data awal yang akan digunakan sebagai acuan dalam pengembangan produk di tahapan selanjutnya. Kedua, tahap pengembangan produk. Tahap pengembangan produk dilakukan dengan tujuan membuat produk sesuai dengan hasil analisis ketubutuhan dan studi pendahuluan. Ketiga, tahap validasi produk. Tahap ini dilaksanakan dengan tujuan memeroleh masukan para ahli sebagai bahan revisi. Keempat, iji coba produk. Produk yang telah dikembangkan diujicobakan secara terbatas dan secara luas. Adapun dalam penelitian ini, peneliti melakukan sampai tahap ketiga. Tujuan peneliti ialah ingin 
mengetahui tingkat kelayakan produk yang dikembangkan. Uji kelayakan pada penelitian ini dilakukan kepada tiga ahli yaitu ahli bahasa, ahli materi (psikologi), dan ahli modul (buku). Uji kelayakan dilakukan sesuai dengan standart kelayakan BSNP yang dilihat dari komponen kelayakan isi, komponen kelayakan bahasa, dan komponen kelayakan penyajian, dan kelayakan kegrafikan.

\section{HASIL DAN PEMBAHASAN}

Buku santun berbahasa untuk pengasuhan berbahasa peserta didik TK di kabupaten Kudus disusun sebagai upaya memberi pemahaman pada guru tentang pentingnya kesantunan berbahasa saat berinteraksi dengan peserta didik. Buku santun berbahasa didesain dalam tiga bagian. Bagian Pendahuluan, bagian isi, dan bagian penyudah. Bagian pendahuluan terdiri atas: halaman judul, prakata, petunjuk penggunaan buku, dan daftar isi. Adapun bagian penyudah terdiri atas: tips, daftar pustaka, dan biografi penulis.

Tahap selanjutnya setelah draf buku tersusun adalah uji kelayakan buku. Kriteria utama dalam menentukan kelayakan sebuah buku atau modul adalah hasil uji kelayakan oleh pakar. Uji kelayakan buku santun berbahasa untuk pengasuhan berbahasa peserta didik TK dilakukan sesuai dengan standart dari Badan Standar Nasional Pendidikan (BSNP) yang meliputi empat hal yakni kelayakan isi, kelayakan bahasa, kelayakan penyajian, dan kelayakan kegrafikan. Uji kelayakan oleh pakar dilakukan untuk mengetahui apakah buku santun berbahasa yang telah disusun secara rinci layak digunakan dalam pembelajaran materi berbahasa pada peserta didik di TK. Adapun rekapitulasi uji kelayakan oleh tiga pakar terhadap kelayakan buku santun berbahasa untuk pengasuhan berbahasa peserta didik TK di kabupaten Kudus dapat dilihat pada Tabel. 2 berikut ini.
Skor 137, 128, dan 143 dari total skor 160 adalah hasil penilaian dari tiga validator sehingga menunjukkan hasil penilaian termasuk dalam kriteria layak. Selain memberikan penilaian, validator juga memberikan kritik dan saran secara langsung mengenai tata tulis, desain, bahasa, dan kesesuaian isi materi dengan tingkat perkembangan peserta didik usia prasekolah. Validator memberikan masukan pada beberapa komponen isi, bahasa yang digunakan, penyajian, dan kegrafikan. Pada komponen bahasa, yang menjadi masukan adalah penggunaan huruf kapital, penulisan kata hubung dan kata sambung, serta tanda baca. Komponen isi mendapat masukan dari validator tentang pemilihan kata dalam materi harus disesuaikan dengan tahap perkembangan bahasa anak usia prasekolah supaya dapat dipahami. Komponen penyajian diberikan masukan untuk memakai tata letak atau lay out yang sesuai dengan ketertarikan desain atau gambar usia anak prasekolah. Masukan untuk komponen kegrafikan adalah penggunaan jenis font, ukuran font dan pemilihan gambar dalam buku santun berbahasa untuk pengasuhan berbahasa peserta didik TK. Masukan dan saran validator kemudian digunakan peneliti untuk memerbaiki buku santun berbahasa untuk pengasuhan berbahasa peserta didik TK. Tabel 3 berikut ini menyajikan rekapitulasi saran dari validator dan tindak lanjut perbaikan oleh peneliti.

Buku santun berbahasa untuk pengasuhan berbahasa peserta didik TK direvisi berdasarkan saran dan masukan dari tiga validator. Buku yang telah direvisi selanjutnya diuji coba skala terbatas pada 15 siswa responden. Uji coba terbatas dilakukan untuk memeroleh masukan sebagai perbaikan sebelum buku digunakan untuk uji coba skala luas.

Petty dan Jansen (1980) menjelaskan Taman Kanak-Kanak merupakan pondasi peletak awal pengetahuan tentang berbahasa. Oleh karena itu, pembelajaran berbahasa di TK harus menyentuh

Tabel 2. Rekapitulasi Kelayakan Buku Santun Berbahasa untuk Pengasuhan Berbahasa Peserta Didik TK

\begin{tabular}{|l|l|l|l|l|}
\hline \multirow{2}{*}{ No } & \multirow{2}{*}{ Aspek yang dinilai } & Skor & \\
\cline { 3 - 5 } & & Validator 1 & Validator 2 & Validator 3 \\
\hline 1 & Komponen Kelayakan Isi & 22 & 24 & 23 \\
\hline 2 & Komponen Kelayakan Bahasa & 29 & 31 & 35 \\
\hline 3 & Komponen Kelayakan Penyajian & 23 & 19 & 22 \\
\hline 4 & Komponen Kelayakan Kegrafikan & 61 & 54 & 63 \\
\hline Total & 137 & 128 & 143 \\
\hline Persentase & $84,3 \%$ & $80 \%$ & $89,3 \%$ \\
\hline Keterangan & Sangat Layak & Layak & Sangat Layak \\
\hline
\end{tabular}


Tabel. 3 Rekapitulasi saran validator terhadap Buku Santun Berbahasa untuk Pengasuhan Berbahasa Peserta Didik TK

\begin{tabular}{|l|l|l|l|}
\hline No & Validator & Saran & Revisi \\
\hline 1. & Validator 1 & $\begin{array}{l}\text { Pemilihan kata sebaiknya menggunakan } \\
\text { kata-kata yang mudah dipahami oleh } \\
\text { peserta didik }\end{array}$ & $\begin{array}{l}\text { Kata yang dianggap sulit } \\
\text { dipahami oleh peserta didik } \\
\text { diganti dengan kata lain yang } \\
\text { lebih mudah dipahami }\end{array}$ \\
\hline 2. & Validator 1 & $\begin{array}{l}\text { Sebaiknya menggunakan kata sapaan yang } \\
\text { menunjukkan memberi motivasi. Seperti } \\
\text { "anak yang hebat", anak yang cerdas" }\end{array}$ & $\begin{array}{l}\text { Kata sapaan yang semula "kalian" } \\
\text { diganti dengan "anak yang hebat", } \\
\text { "anak yang cerdas" }\end{array}$ \\
\hline 3 & Validator 2 & $\begin{array}{l}\text { Penggunaan tanda baca, penulisan kata } \\
\text { hubung, penulisan kata sambung, dan } \\
\text { penulisan huruf kapital diperhatikan }\end{array}$ & $\begin{array}{l}\text { Memperbaiki penggunaan tanda } \\
\text { baca, penulisan kata hubung, } \\
\text { penulisan kata sambung, dan } \\
\text { penulisan huruf kapital. }\end{array}$ \\
\hline 4 & Validator 3 & $\begin{array}{l}\text { Lay out belum menarik. gambar animasi } \\
\text { masih kurang. }\end{array}$ & $\begin{array}{l}\text { Mengganti lay out yang tidak } \\
\text { menarik menjadi lebih menarik } \\
\text { dengan memerbanyak gambar } \\
\text { animasi. }\end{array}$ \\
\hline 5 & Validator 3 & Beberapa gambar belum terlihat jelas & $\begin{array}{l}\text { Memperbesar resolusi gambar } \\
\text { yang kurang jelas }\end{array}$ \\
\hline
\end{tabular}

kesantunan. Melalui pemahaman santun berbahasa sejak dini, anak akan terbentuk dan terbiasa dalam santun berbahasa.

Derrich (1984) melakukan penelitian tentang karakteristik interaksi vokal antara guru dan peserta didik yang membuktikan bahwa terdapat hubungan timbal balik atau respons bersama (mutual responsive) antara guru dan peserta didik; bisa dikatakn, apa yang diujarkan oleh guru maka direspon oleh peserta didik atau sebaliknya. Respon guru sangat penting bagi perkembangan bahasa anak-anak. Interaksi percakapan tersebut merupakan sarana pokok bagi guru untuk menafsirkan peristiwa sehari-hari dan menggunakan makna tersebut sebagai sumber pemahaman terhadap berbagai kegiatan.

Studi pendahuluan dan analisis kebutuhan yang telah dilakukan sebelumnya merupakan dasar dilakukannya pengembangan buku santun berbahasa untuk pengasuhan berbahasa peserta didik TK. Melihat hasil pengamatan pada buku pengajaran bahasa untuk TK di pasaran yang belum memuat kesantunan dan kebutuhan guru untuk memiliki buku guru sebagai pedoman mengajarkan kesantunan berbahasa juga menjadi faktor penting dari disusunnya buku santun berbahasa.

Salimuddin (2012) dalam penelitiannya yang berjudul "Pengasuhan Berbahasa untuk Anak Usia Prasekolah" yang dimuat dalam Jurnal Linguistik Indonesia menjelaskan, bahwa anakanak usia prasekolah sangat perlu untuk diberi pemahaman dan pembiasaan kesantunan berbahasa.

Buku santun berbahasa untuk pengasuhan berbahasa peserta didik TK divalidasi oleh tiga validator. Hasil validasi ketiga validator menunjukkan bahwa buku santun berbahasa yang dikembangkan layak digunakan sebagai bahan ajar guru di Taman Kanak-kanak. . Berdasarkan hasil uji kelayakan dari tiga validator diperoleh skor 137, 128, dan 143 dari total skor 160, sehingga hasil penilaian termasuk dalam kriteria layak. Selain itu, validator juga memberikan saran dan masukan yang digunakan dalam perbaikan buku. Berdasarkan hasil tersebut, dapat disimpulkan buku yang dikembangkan layak untuk digunakan sebagai bahan ajar guru untuk pembelajaran berbahasa di TK.

Adapun kekurangan buku santun berbahasa untuk pengasuhan berbahasa peserta didik TK terletak pada pemilihan gambar animasi yang masih kurang. Hal tersebut dikarenakan beberapa gambar animasi yang dibutuhkan tidak tersedia sehingga akan terlihat tidak menarik. Saran validator untuk memerbanyak menggunakan gambar animasi agar tidak menjadikan minat baca siswa menurun. Haryanto (2009) menyatakan bahwa kemenarikan animasi yang digunakan dalam pembelajaran akan memberikan pengaruh terhadap ketrampilan membaca dan menulis dari siswa. Kekurangan dari buku tersebut telah diperbaiki oleh peneliti dengan menambah gambar animasi agar buku terlihat lebih menarik. 
Aspek lain yang menjadi kekurangan dari buku santun berbahasa adalah komponen halaman judul dan petunjuk penggunaan buku. Menurut validator, sampul perlu ditambah keterangan semester, karena buku yang dikembangkan untuk kebutuhan pembelajaran satu tahun. Petunjuk penggunaan buku menunjukkan belum semua komponen buku disebutkan. Setelah peneliti memahami masukan ini, draf buku segera diperbaiki sesuai saran dan masukan validator. Selain komponen pendahulu, validator juga memeriksa keberterimaan komponen isi. Masukan validator adalah mengganti kata yang sulit dipahami oleh peserta didik menjadi kata yang mudah dipahami.

Validator juga memberi masukan pada komponen isi. Dirujuk dari kurikulum, validator melihat adanya ketidaksesuaian antara latihan dengan kegiatan. Ketidak sesuaian antara petunjuk dengan kegiatan dengan kalimat petunjuk. Perbaikan oleh peneliti terus dilakukan. Validator ahli modul juga melihat adanya kesalahan pada materi syair halaman 22 , soal ke-4 tidak ada pilihan yang cocok. Setelah peneliti mengonsultasikannya dengan guru, kesalahan tersebut segera diperbaiki. Buku santun berbahasa memuat kalimat pesan berantai pada halaman 8 . Menurut validator ahli psikologi menyatakan bahawa hal tersebut kurang sesuai untuk perkembangan kognisi anak usia prasekolah.

Validator 1, 2, dan 3 secara umum memberikan simpulan bahwa buku santun berbahasa untuk pengasuhan berbahasa peserta didik TK dapat digunakan sebagai bahan ajar dengan revisi. Beberapa kekurangan dari buku yang dikembangkan telah diperbaiki oleh peneliti antara lain mendesain ulang lay out agar lebih menarik, memerbanyak gambar animasi, memperbaiki tata tulis seperti penggunaan tanda baca, penulisan huruf kapital, penulisan kata sambung dan kata hubung, pemilihan kata yang mudah dipahami, isi materi yang sesuai dengan perkembangan kognisi peserta didik. Kelayakan buku santun berbahasa untuk pengasuhan berbahasa peserta didik TK yang dikembangkan menurut hasil validasi oleh validator masuk dalam kriteria layak dan selanjutnya dapat digunakan untuk uji coba skala terbatas.

\section{SIMPULAN}

Hasil validasi ketiga validator menunjukkan bahwa buku santun berbahasa yang dikembangkan layak digunakan sebagai bahan ajar guru untuk pengasuhan berbahasa di Taman Kanak-kanak. . Berdasarkan hasil uji kelayakan dari tiga validator diperoleh skor 137, 128, dan 143 dari total skor 160, sehingga hasil penilaian termasuk dalam kriteria layak. Adapun rincian sebagai berikut. Validator ahli materi (psikolog) dengan aspek kelayakan isi, kelayakan bahasa, kelayakan penyajian, dan kelayakan kegrafikan sebesar 84,3\% yang berarti dalam kategori sangat layak. Untuk skor uji kelayakan dari ahli bahasa dengan aspek kelayakan isi, kelayakan bahasa, kelayakan penyajian, dan kelayakan kegrafikan didapatkan hasil sebesar $80 \%$ yang berarti dalam kategori layak. Skor uji kelayakan dari ahli modul (buku) dengan aspek kelayakan isi, kelayakan bahasa, kelayakan penyajian, dan kelayakan kegrafikan sebesar $89,3 \%$ yang juga dalam kategori sangat layak. Sehingga dapat disimpulkan bahwa buku santun berbahasa untuk pengasuhan berbahasa yang sudah mendapatkan masukan para ahli dan guru dalam kategori layak.

\section{SARAN}

Adapun saran berdasarkan hasil penelitian ini, yakni (1) guru sebaiknya menggunakan buku santun berbahasa untuk pembelajaran berbahasa di TK; (2) penyusun buku ajar TK sebaiknya menyusun buku berdasar pada kesantunan berbahasa; dan (3) pemerintah atau pemangku kebijakan di lingkungan pendidikan sebaiknya menyusun instruksi yang berkaitan dengan materi berbahasa untuk TK.

\section{DAFTAR PUSTAKA}

Derrich, June. 1984. The Child's Acquisition of Language. England: National Foundation for Educational Research.

Eelen, Gino. 2001. A Critique of Politeness Theories. Manchester: St. Jerome Publishing.

Haryanto. 2009. Upaya Meningkatkan Kemampuan Membaca dan Menulis Permulaan dengan Media Gambar (Tesis). Surakarta: UNS.

Gall, Meredith D., Joyce P. Gall, dan Walter R. Borg. 1983. Educational Research An Introduction $\left(7^{\text {th }}\right.$ ed.). New York: Pearson Education, Inc.

Millah ES, Budipramana LS \& Isnawati. 2012. Pengembangan Buku Ajar Materi Bioteknologi di Kelas XII SMA IPIEMS Surabaya Berorientasi Sains Teknologi Lingkungan dan Masyarakat (SETS). EJournal Unesa BioEdu. 1(1): 19-24

Petty, Walter T. dan Julie M. Jensen. 1980. Developing Children's Language. Boston: Allyn and Bacon Inc.

Salimuddin .2012. "Pengasuhan Berbahasa untuk Anak Usia Prasekolah” Tesis. Semarang: UNIKA Soegijapranata. 